\title{
Cellulosilyticum ruminicola gen. nov., sp. nov., isolated from the rumen of yak, and reclassification of Clostridium lentocellum as Cellulosilyticum lentocellum comb. nov.
}

\author{
Shichun Cai ${ }^{1,2}$ and Xiuzhu Dong ${ }^{1}$ \\ ${ }^{1}$ State Key Laboratory of Microbial Resources, Institute of Microbiology, Chinese Academy of \\ Sciences, Beijing 100101, PR China \\ ${ }^{2}$ Graduate School of Chinese Academy of Sciences, Beijing 100049, PR China
}

Correspondence

Xiuzhu Dong

dongxz@sun.im.ac.cn
Lignocellulose is the main component of biomass generated by photosynthesis (Pérez et al., 2002) and it is degraded and utilized by various micro-organisms in nature (Beguin \& Aubert, 1994). It is well known that ruminant rumens harbour abundant fibrolytic anaerobes that enable them to live on lignocellulose-based plant straws. Therefore, rumen microbiology has been studied for the primary fibrolytic potential. The yak (Bos grunniens) is a ruminant living mainly on QinghaiTibetan Plateau, China, more than $3000 \mathrm{~m}$ above sea level, and grazes exclusively on grasses and straws. Hence, it is reasonable to speculate that fibrolytic anaerobes could be active in yak rumen. In this study, we describe the isolation and characterization of a fibrolytic strain isolated from the rumen of a domesticated yak.

\footnotetext{
The GenBank/EMBL/DDBJ accession number for the 16S rRNA gene sequence of strain $\mathrm{H}^{\top}$ is EF382648.

A supplementary table showing the cellular fatty acid composition of strain $\mathrm{H}^{\top}$ is available with the online version of this paper.
}

RC medium, a modified RGCA medium (Bryant \& Burkey, 1953), containing (per $100 \mathrm{ml}$ ): $40 \mathrm{ml}$ yak rumen fluid, $30 \mathrm{ml}$ distilled water, $2.0 \mathrm{~g}$ Whatman No. 1 filter paper, $0.05 \mathrm{~g}$ cysteine hydrochloride, $20 \mu \mathrm{l} 0.2 \%$ resazurin, $45 \mathrm{mg}$ $\mathrm{K}_{2} \mathrm{HPO}_{4}, 45 \mathrm{mg} \mathrm{KH} \mathrm{PO}_{4}, 90 \mathrm{mg}\left(\mathrm{NH}_{4}\right)_{2} \mathrm{SO}_{4}, 90 \mathrm{mg} \mathrm{NaCl}$, $9 \mathrm{mg} \mathrm{MgSO}_{4}, 9 \mathrm{mg} \mathrm{CaCl}$ and $1 \%$ sodium bicarbonate $(\mathrm{w} / \mathrm{v})$, was prepared with $100 \% \mathrm{CO}_{2}$ as the gas phase. After sterilization, the $\mathrm{pH}$ of the medium was $\mathrm{pH}$ 6.7. $\mathrm{RC}-\mathrm{CB}$ medium was prepared by adding $0.2 \mathrm{~g}$ cellobiose per $100 \mathrm{ml}$ instead of filter paper. These media were used for the isolation of strain $\mathrm{H}^{\mathrm{T}}$ at $38{ }^{\circ} \mathrm{C}$ in anaerobic tubes sealed with butyl rubber stoppers. RC medium was inoculated with rumen content and, after subculturing the enrichment several times, was used to inoculate RC-CB medium. A pure culture of strain $\mathrm{H}^{\mathrm{T}}$ was obtained by using serial dilution and the Hungate roll-tube technique (Hungate, 1969) and finally picking single colonies to inoculate RC-CB medium, which was incubated at $38{ }^{\circ} \mathrm{C}$ for 2 days. The purity of strain $\mathrm{H}^{\mathrm{T}}$ was examined microscopically for cell morphology and colony homogeneity. Clostridium lentocellum DSM $5427^{\mathrm{T}}$ was obtained from the 
DSMZ, Germany. Both strains were cultured routinely in $\mathrm{RC}-\mathrm{CB}$ medium ( $\mathrm{pH} 6.7$ ) at $38{ }^{\circ} \mathrm{C}$ unless otherwise indicated.

Cell morphology was examined both under a light microscope (Olympus BH-2) and an electron microscope (Hitachi H-600A). For electron microscope examination of ultrathin cell-wall sections, cells were grown in RC-CB medium for 1 day and prepared by using the method described previously (Chen \& Dong, 2005). Cells of strain $\mathrm{H} 1^{\mathrm{T}}$ were Gram-negative-staining throughout the growth phase; however, a typical Gram-positive structure was revealed by electron microscopy (Fig. 1). Cells were straight to slightly curved rods, $0.8-1.0 \times 3.0-4.0 \mu \mathrm{m}$ in size and encapsulated by abundant slime. Flagella were never observed. Strain $\mathrm{H}^{\mathrm{T}}$ grew exclusively in the pre-reduced media and growth was completely inhibited by air. Elliptical spores were occasionally formed, which swelled the cells at one terminal. Colonies on RC-CB agar medium were yellow-green, circular and slightly convex, 1.0$2.0 \mathrm{~mm}$ in diameter after 1 day of incubation.

The fermentation products of strain $\mathrm{H}^{\mathrm{T}}$ and Clostridium lentocellum DSM $5427^{\mathrm{T}}$ were determined using GC (GC14B; Shimadzu) and gaseous products were determined by GC-14C (Shimadzu), according to Chen \& Dong (2004), after culture in RC medium for 7 days and in RC-CB medium for 3 days. The major fermentation products of strain $\mathrm{H}^{\mathrm{T}}$ were formic acid, acetic acid and carbon dioxide. Trace amounts of ethanol, lactic acid and succinic acid were also produced. Clostridium lentocellum DSM $5427^{\mathrm{T}}$ produced ethanol, acetic acid, hydrogen, carbon dioxide and trace amounts of lactic, succinic and fumaric acids (Table 1).

The temperature range for growth of strain $\mathrm{H}^{\mathrm{T}}$ was determined in RC-CB medium in a water bath at $22-50{ }^{\circ} \mathrm{C}$ with intervals of $1{ }^{\circ} \mathrm{C}$. To determine the $\mathrm{pH}$ range for growth, $30 \% \mathrm{CO}_{2}$ and $70 \% \mathrm{~N}_{2}$ was used as the gas phase

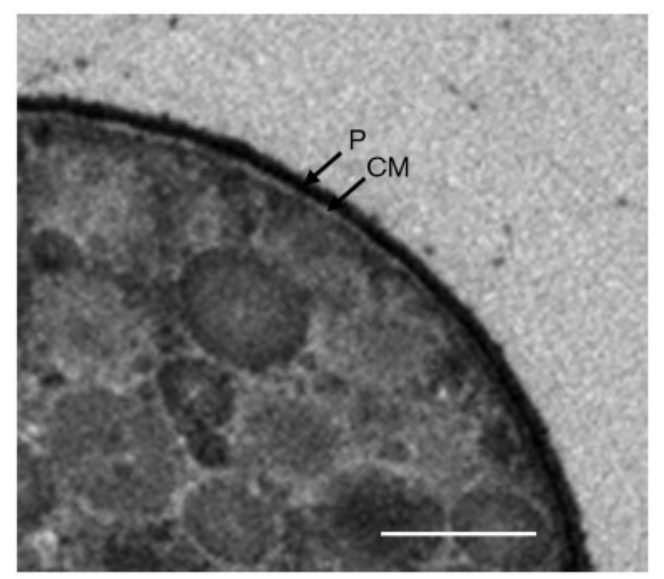

Fig. 1. Electron micrograph of an ultrathin section of a cell of strain $\mathrm{H} 1^{\top}$. CM, cytoplasmic membrane; $\mathrm{P}$, peptidoglycan. Bar, $0.1 \mu \mathrm{m}$.
Table 1. Differential characteristics of Cellulosilyticum ruminicola sp. nov. $\mathrm{H}^{\top}$ and Cellulosilyticum lentocellum DSM $5427^{\top}$

All data were from this study. Both strains were positive for utilization of cellobiose, cellulose and xylose. + , Positive; w, weak; - , negative.

\begin{tabular}{|lcc|}
\hline Characteristic & $\begin{array}{c}\text { C. ruminicola } \\
\mathbf{H 1}^{\mathbf{T}}\end{array}$ & $\begin{array}{c}\text { C. } \text { lentocellum } \\
\text { DSM } \mathbf{5 4 2 7}^{\mathbf{T}}\end{array}$ \\
\hline Cell morphology & $\begin{array}{c}\text { Straight to slightly } \\
\text { curved rods }\end{array}$ & $\begin{array}{c}\text { Slightly curved } \\
\text { rods }\end{array}$ \\
Motility & - & + \\
Utilization of: & - & + \\
Fructose & - & $\mathrm{W}$ \\
Galactose & - & + \\
Starch & - & + \\
Sucrose & - & $\mathrm{W}$ \\
Trehalose & + & $\mathrm{W}$ \\
Xylan & $\mathrm{A}, \mathrm{F}, \mathrm{e}, \mathrm{l}, \mathrm{s}$ & $\mathrm{A}, \mathrm{E}, \mathrm{l}, \mathrm{fu}, \mathrm{s}$ \\
Fermentation products & & 36 \\
DNA G + C content $(\mathrm{mol} \%)$ & 33.7 & \\
\hline
\end{tabular}

${ }^{\star}$ Upper-case letters indicate major end products and lower-case letters indicate minor end products. a, acetate; e, ethanol; f, formate; fu, fumaric acid; l, lactic acid; s, succinic acid.

for RC-CB medium ( $\mathrm{pH} 7.0$ ) and the medium was adjusted to $\mathrm{pH} 5.0-10.0$ by using $1 \mathrm{M} \mathrm{HCl}$ or $1 \mathrm{M}$ $\mathrm{NaOH}$. The $\mathrm{pH}$ range for growth was determined at $38{ }^{\circ} \mathrm{C}$. Growth was determined by measuring $\mathrm{OD}_{600}$ of cultures at 3 and 7 days in duplicate. Strain $\mathrm{H}^{\mathrm{T}}$ grew at $25-45{ }^{\circ} \mathrm{C}$, with optimum growth at $38{ }^{\circ} \mathrm{C}$, and at $\mathrm{pH} 6.0$ 7.8 , with optimum growth at $\mathrm{pH}$ 6.7. The generation time of strain $\mathrm{H}^{\mathrm{T}}$ was determined as $2.85 \mathrm{~h}$ by monitoring $\mathrm{OD}_{600}$ in RC-CB medium at $0.5 \mathrm{~h}$ intervals for $24 \mathrm{~h}$.

Biochemical tests were performed according to the procedures described by Holdeman et al. (1977). Strain $\mathrm{H}^{\mathrm{T}}$ did not produce indole, catalase, gelatinase, urease or acetyl-methyl-carbinol, did not reduce sulfate or nitrate and did not hydrolyse aesculin.

Substrate utilization tests were performed according to Murray et al. (1986) in RC medium by addition of various tested substances instead of filter paper. Utilization was defined as the increase of $\mathrm{OD}_{600}$ by 0.1 . In addition to cellulose, strain $\mathrm{H}^{\mathrm{T}}$ used cellobiose $(0.5 \%)$, xylan $(0.5 \%)$, xylose $(0.5 \%)$ and maltose $(0.5 \%)$ as sole carbon and energy sources. The substrate profile of Clostridium lentocellum DSM $5427^{\mathrm{T}}$ was tested in parallel. More details are given in Table 1 and the genus and species descriptions.

Cellular fatty acids of strain $\mathrm{H}^{\mathrm{T}}$ were extracted from exponential-phase cells from 1-day cultures in RC-CB medium. The extracts were methylated and analysed using the standard Microbial Identification system (Miller, 1982; Sasser, 1990). The major cellular fatty acids were $C_{16: 0}$ (27.1\%), $\mathrm{C}_{14: 0} \quad(9.2 \%)$, iso- $\mathrm{C}_{16: 0} \quad(6.4 \%), \mathrm{C}_{16: 1} \omega 9 \mathrm{c}$ 


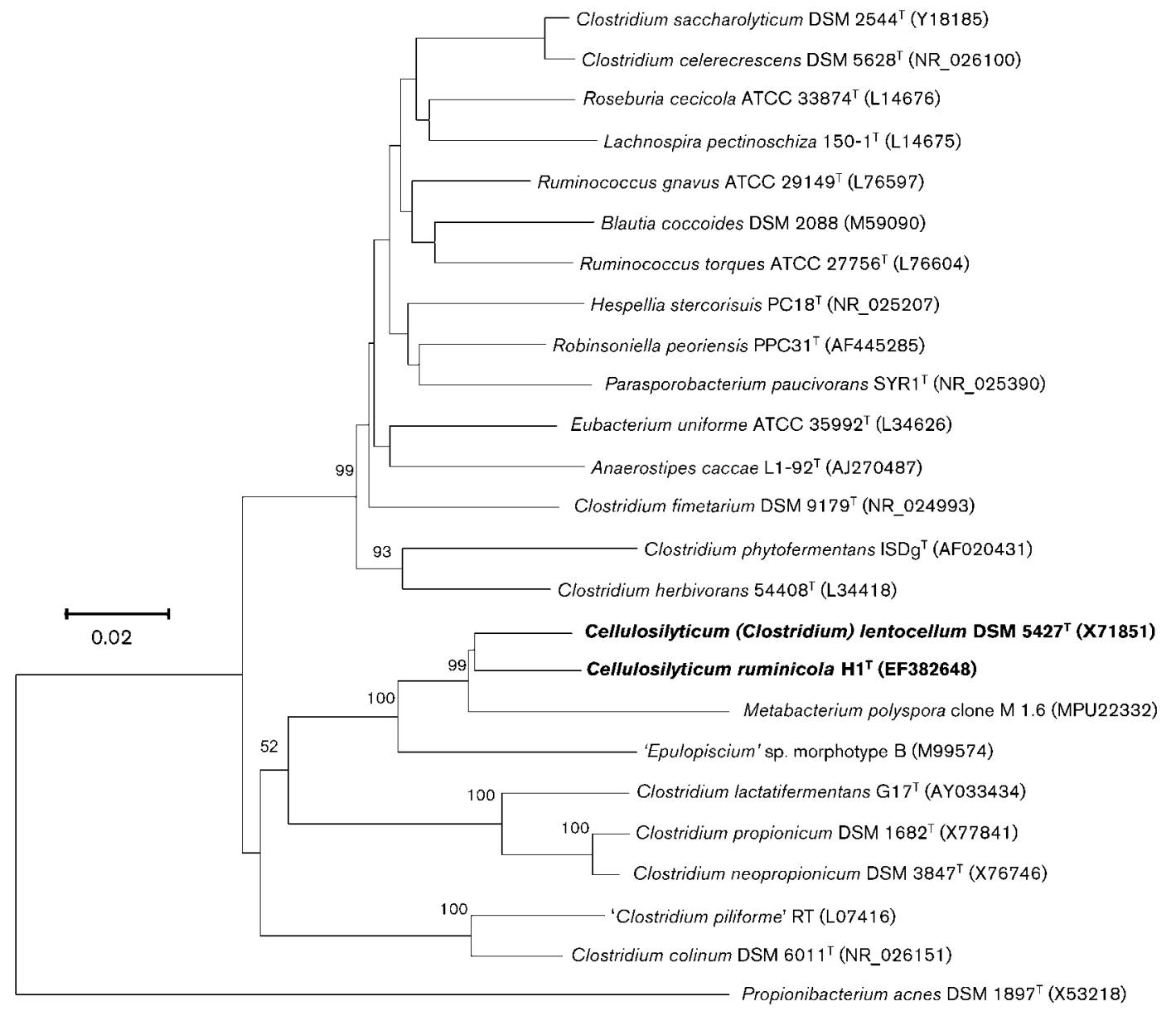

Fig. 2. Phylogenetic dendrogram of strain $\mathrm{H}^{\top}$ and related strains based on $16 \mathrm{~S}$ rRNA gene sequences, constructed using the neighbour-joining method. Bootstrap values $(>50 \%)$ based on 1000 resamplings are shown at branch nodes. Propionibacterium acnes DSM $1897^{\top}$ was used as an outgroup. Bar, $2 \%$ sequence divergence.

$(4.7 \%)$ and $\mathrm{C}_{18: 1} \omega 7 c(4.7 \%)$ (Supplementary Table $\mathrm{S} 1$, available in IJSEM Online).

The genomic DNA was extracted and purified using the method of Jaufeerally-Fakim \& Dookun (2000). The G + C content of the genomic DNA was determined to be $33.7 \pm 1.2 \mathrm{~mol} \%$ by using the thermal denaturation method (Marmur \& Doty, 1962) with a DU800 spectrophotometer (Beckman) and Escherichia coli K-12 as the reference strain. To determine the phylogenetic position of strain $\mathrm{H}^{\mathrm{T}}$, the $16 \mathrm{~S}$ rRNA gene sequence was amplified by PCR and sequenced as described previously (Chen \& Dong, 2004). The $16 \mathrm{~S}$ rRNA gene sequence (1547 bp) was submitted to GenBank to search for similar sequences using the BLAST algorithm. The best-matching sequences were retrieved from the database and aligned, and a similarity analysis was performed using CLUSTAL_X (Thompson et al., 1997). A phylogenetic tree (Fig. 2) based on 1268 bp 16S rRNA gene sequence was constructed using neighbour-joining methods implemented with MEGA2 software (Kumar et al., 2001). The robustness of the tree was evaluated by bootstrap analysis (Felsenstein, 1985) with 1000 resamplings.

The phylogenetic analysis showed that strain $\mathrm{H}^{\mathrm{T}}$ had the highest 16S rRNA gene sequence similarity (96.0\%) with Clostridium lentocellum DSM $5427^{\mathrm{T}}$. These two strains formed a distinct lineage within the clostridial rRNA cluster XIVb with the unculturable polysporogenic strain 'Metabacterium polyspora' clone M 1.6 and 'Epulopiscium' sp. morphotype B. The lineage was supported by a bootstrap value of $99 \%$ and exhibited 16S rRNA gene sequence similarities of less than $87.7 \%$ with other species in cluster XIVb. Collins et al. (1994) proposed 19 rRNA clusters for Clostridium members because this genus is extremely heterogeneous and species in clusters II-XIX all fell outside the genus Clostridium sensu stricto. Recently, species in cluster XIVb were reassigned to the family 'Lachnospiraceae' (Wiegel et al., 2006). On the basis of $16 \mathrm{~S}$ rRNA gene sequence divergence, this study concluded that strain $\mathrm{H}^{\mathrm{T}}$ and Clostridium lentocellum DSM $5427^{\mathrm{T}}$ represent a new genus of the family 'Lachnospiraceae'. 
The cellulolytic property is found in many phylogenetically diverse clostridial species (Rainey \& Stackebrandt, 1993) and many of them fall into the rRNA clusters III and XIVa. Phenotypically, the strain $\mathrm{H}^{\mathrm{T}}$ and Clostridium lentocellum DSM $5427^{\mathrm{T}}$ differed from the phylogenetically related species Clostridium lactatifermentans, Clostridium propionicum and Clostridium neopropionicum in their capabilities to hydrolyse cellulose and xylan and inabilities to ferment lactate and pyruvate (van der Wielen et al., 2002; Cardon \& Barker, 1946; Tholozan et al., 1992). Furthermore, all of these three non-fibrolytic species produce propionate as the major fermentation product whereas strain $\mathrm{H}^{\mathrm{T}}$ and Clostridium lentocellum DSM $5427^{\mathrm{T}}$ did not. Strain $\mathrm{H}^{\mathrm{T}}$ and Clostridium lentocellum DSM $5427^{\mathrm{T}}$ could also be distinguished from other phylogenetically related genera in the family 'Lachnospiraceae' as follows: from the genera of Roseburia, Hespellia and Anaerostipes by the ability to sporulate and inability to produce butyric or propionic acids (Stanton \& Savage, 1983; Whitehead et al., 2004; Schwiertz et al., 2002); from the genus Robinsoniella by the absence of succinate as a major end product (Cotta et al., 2009); from Lachnospira by cell and colony morphology (filamentous and woolly, respectively, for Lachnospira; Cornick et al., 1994); and from the genus Parasporobacterium by the ability to grow without sulfide (Lomans et al., 2001).

On the basis of the collective data presented above, a novel genus Cellulosilyticum gen. nov. is proposed, consisting of the newly isolated Cellulosilyticum ruminicola sp. nov. and Cellulosilyticum lentocellum comb. nov.

\section{Description of Cellulosilyticum gen. nov.}

Cellulosilyticum [Cel.lu.lo.si.ly'ti.cum. N.L. n. cellulosum cellulose; N.L. neut. adj. lyticum (from Gr. neut. adj. lutikon) able to loosen, able to dissolve; N.L. neut. n. Cellulosilyticum a bacterium able to dissolve cellulose].

Straight to slightly curved rod-shaped cells $(0.3-1.0 \times 2.5-$ $4.0 \mu \mathrm{m})$. Cells form terminal spores. Anaerobic. Mesophilic, optimum growth temperature is approximately $40{ }^{\circ} \mathrm{C}$. Produce acetate as one of the major end products. Butyric acid is not formed. Hydrolyse cellulose and xylan and ferment cellobiose. The DNA G $+\mathrm{C}$ content is 32.9$36 \mathrm{~mol} \%$. The type species is Cellulosilyticum ruminicola.

\section{Description of Cellulosilyticum ruminicola sp. nov.}

Cellulosilyticum ruminicola [ru.mi.ni' co.la. L. n. rumen -inis the rumen; L. suff. -cola (from L. n. incola) inhabitant, dweller; N.L. n. ruminicola rumen dweller].

Exhibits the following properties in addition to those given in the genus description. Cells are Gram-negative-staining but have a Gram-positive cell-wall structure and are 0.8$1.0 \times 3.0-4.0 \mu \mathrm{m}$ in size, occurring singly. Cells are nonmotile and encapsulated with slime. Elliptical and terminal spores are produced occasionally. Colonies are yellow- green, circular and slightly convex, $1.0-2.0 \mathrm{~mm}$ in diameter. Obligate anaerobic growth. Growth occurs at 25-45 ${ }^{\circ} \mathrm{C}$ (optimum, $38{ }^{\circ} \mathrm{C}$ ) and at $\mathrm{pH}$ 6.0-7.8 (optimum, $\mathrm{pH}$ 6.7). Indole, catalase, gelatinase, urease and acetylmethyl-carbinol are not produced. Sulfate and nitrate are not reduced. Does not hydrolyse aesculin. Ferments xylose and maltose and weakly ferments lactose, pectin and sorbitol. Does not utilize arabinose, fructose, galactose, glucose, glycogen, pyruvate, sucrose, trehalose, starch, amygdalin, erythritol, glycerol, inositol, lactate, mannitol, melezitose, melibiose, raffinose, rhamnose, ribose, salicin, hippurate or mannose. Fermentation products from cellulose and cellobiose are formic acid, acetic acid, carbon dioxide and trace amounts of ethanol, succinic acid and lactic acid. Major cellular fatty acids are $\mathrm{C}_{16: 0}, \mathrm{C}_{14: 0}$, iso$\mathrm{C}_{16: 0}, \mathrm{C}_{16: 1} \omega 9 c$ and $\mathrm{C}_{18: 1} \omega 7 c$. The DNA G $+\mathrm{C}$ content of the type strain is $33.7 \pm 1.2 \mathrm{~mol} \%$.

The type strain, $\mathrm{H1}^{\mathrm{T}}\left(=\mathrm{CGMCC} 1.5065^{\mathrm{T}}=\mathrm{JCM} 14822^{\mathrm{T}}\right)$, was isolated from the rumen of yak.

\section{Description of Cellulosilyticum lentocellum comb. nov.}

Cellulosilyticum lentocellum (len.to.cel'lum. L. adj. lentus slow; N.L. n. cellulosum cellulose; N.L. neut. adj. lentocellum intended to mean slowly fermenting cellulose).

Basonym: Clostridium lentocellum Murray et al. 1987.

Characteristics are those as given by Murray et al. (1986) and from this study. Cells are Gram-negative-staining, motile, slightly curved rods, $0.3-0.5 \times 2.5-4.0 \mu \mathrm{m}$ in size, occurring singly. Cells form round terminal spores. Colonies are flat, colourless and transparent with undulate margins, 7-10 mm in diameter. Obligate anaerobic growth. Growth occurs at $15-46.5{ }^{\circ} \mathrm{C}$ (optimum, $40{ }^{\circ} \mathrm{C}$ ) and $\mathrm{pH}$ 5.7-9.13 (optimum, $\mathrm{pH}$ 7.5-7.7). Indole, catalase, gelatinase are not produced. Sulfate and nitrate are not reduced. Acetyl-methyl-carbinol is produced and urease is weakly produced. Utilizes arabinose, cellobiose, cellulose, aesculin, fructose, galactose, glucose, glycogen, lactose, maltose, pyruvate, salicin, sucrose, trehalose, xylose, xylan, milk, starch, bile and chopped meat. Does not utilize adonitol, amygdalin, arginine, dulcitol, erythritol, glycerol, hippurate, inositol, inulin, lactate, mannitol, mannose, melezitose, melibiose, raffinose, rhamnose, ribose, sorbitol, sorbose or threonine. Major fermentation products from cellulose are ethanol, acetic acid, hydrogen and carbon dioxide. The DNA G + C content of the type strain is $36 \mathrm{~mol} \%$.

The type strain, RHM $^{\mathrm{T}} \quad\left(=\mathrm{ATCC} \quad 49066^{\mathrm{T}}=\mathrm{DSM}\right.$ $5427^{\mathrm{T}}=$ NCIMB $11756^{\mathrm{T}}$ ), was isolated from an estuarine mud bank of a river receiving paper-mill and domestic effluent.

\section{Acknowledgements}

We thank Jin Han for performing the electron microscopy and Kegui Zhang and Dengdi An for providing the rumen content. We thank Lei 
Song and Lili Niu for the critical discussion on the determination of genomic DNA G + C content. This study was supported by National Basic Research Program of China (2004CB719602).

\section{References}

Beguin, P. \& Aubert, J. P. (1994). The biological degradation of cellulose. FEMS Microbiol Rev 13, 25-58.

Bryant, M. P. \& Burkey, L. A. (1953). Cultural methods and some characteristics of some of the more numerous groups of bacteria in the bovine rumen. J Dairy Sci 36, 205-217.

Cardon, B. P. \& Barker, H. A. (1946). Two new amino-acidfermenting bacteria, Clostridium propionicum and Diplococcus glycinophilus. J Bacteriol 52, 629-634.

Chen, S. \& Dong, X. (2004). Acetanaerobacterium elongatum gen. nov., sp. nov., from paper mill waste water. Int J Syst Evol Microbiol 54, 2257-2262.

Chen, S. \& Dong, X. (2005). Proteiniphilum acetatigenes gen. nov., sp. nov., from a UASB reactor treating brewery wastewater. Int J Syst Evol Microbiol 55, 2257-2261.

Collins, M. D., Lawson, P. A., Willems, A., Cordoba, J. J., FernandezGarayzabal, J., Garcia, P., Cai, J., Hippe, H. \& Farrow, J. A. E. (1994). The phylogeny of the genus Clostridium: proposal of five new genera and eleven new species combinations. Int J Syst Bacteriol 44, 812-826.

Cornick, N. A., Jensen, N. S., Stahl, D. A., Hartman, P. A. \& Allison, M. J. (1994). Lachnospira pectinoschiza sp. nov., an anaerobic pectinophile from the pig intestine. Int J Syst Bacteriol 44, 87-93.

Cotta, M. A., Whitehead, T. R., Falsen, E., Moore, E. \& Lawson, P. A. (2009). Robinsoniella peoriensis gen. nov., sp. nov., isolated from a swine-manure storage pit and a human clinical source. Int J Syst Evol Microbiol 59, 150-155.

Felsenstein, J. (1985). Confidence limits on phylogenies: an approach using the bootstrap. Evolution 39, 783-791.

Holdeman, L. V., Cato, E. P. \& Moore, W. E. C. (1977). Anaerobe Laboratory Manual, 4th edn. Blacksburg, VA: Virginia Polytechnic Institute and State University.

Hungate, R. E. (1969). A roll tube method for cultivation of strict anaerobes. Methods Microbiol 3B, 117-132.

Jaufeerally-Fakim, Y. \& Dookun, A. (2000). Extraction of high quality DNA from polysaccharides-secreting xanthomonads. Science and Technology-Research Journal of the University of Mauritius 6, 33-40.

Kumar, S., Tamura, K., Jakobsen, I. B. \& Nei, M. (2001). MEGA2: Molecular Evolutionary Genetics Analysis software. Bioinformatics 17, 1244-1245.

Lomans, B. P., Leijdekkers, P., Wesselink, J.-J., Bakkes, P., Pol, A., van der Drift, C. \& Op den Camp, H. J. M. (2001). Obligate sulfidedependent degradation of methoxylated aromatic compounds and formation of methanethiol and dimethyl sulfide by a freshwater sediment isolate, Parasporobacterium paucivorans gen. nov., sp. nov. Appl Environ Microbiol 67, 4017-4023.

Marmur, J. \& Doty, P. (1962). Determination of the base composition of deoxyribonucleic acid from its thermal denaturation temperature. J Mol Biol 5, 109-118.

Miller, L. T. (1982). Single derivatization method for routine analysis of bacterial whole-cell fatty acid methyl esters, including hydroxy acids. J Clin Microbiol 16, 584-586.

Murray, W. D., Hofmann, L., Campbell, N. L. \& Madden, R. H. (1986). Clostridium lentocellum sp. nov., a cellulolytic species from river sediment containing paper-mill waste. Syst Appl Microbiol 8, 181-184.

Pérez, J., Muñoz-Dorado, J., de la Rubia, T. \& Martínez, J. (2002). Biodegradation and biological treatments of cellulose, hemicellulose and lignin: an overview. Int Microbiol 5, 53-63.

Rainey, F. A. \& Stackebrandt, E. (1993). 16S rDNA analysis reveals phylogenetic diversity among the polysaccharolytic clostridia. FEMS Microbiol Lett 113, 125-128.

Sasser, M. (1990). Identification of bacteria by gas chromatography of cellular fatty acids, MIDI Technical Note 101. Newark, DE: MIDI Inc.

Schwiertz, A., Hold, G. L., Duncan, S. H., Gruhl, B., Collins, M. D., Lawson, P. A., Flint, H. J. \& Blaut, M. (2002). Anaerostipes caccae gen. nov., sp. nov., a new saccharolytic, acetate-utilising, butyrateproducing bacterium from human faeces. Syst Appl Microbiol 25, 46-51.

Stanton, T. B. \& Savage, D. C. (1983). Roseburia cecicola gen. nov., sp. nov., a motile, obligately anaerobic bacterium from a mouse cecum. Int J Syst Bacteriol 33, 618-627.

Tholozan, J. L., Touzel, J. P., Samain, E., Grivet, J. P., Prensier, G. \& Albagnac, G. (1992). Clostridium neopropionicum sp. nov., a strict anaerobic bacterium fermenting ethanol to propionate through acrylate pathway. Arch Microbiol 157, 249-257.

Thompson, J. D., Gibson, T. J., Plewniak, F., Jeanmougin, F. \& Higgins, D. G. (1997). The CLUSTAL_X windows interface: flexible strategies for multiple sequence alignment aided by quality analysis tools. Nucleic Acids Res 25, 4876-4882.

van der Wielen, P. W. J. J., Rovers, G. M. L. L., Scheepens, J. M. A. \& Biesterveld, S. (2002). Clostridium lactatifermentans sp. nov., a lactate-fermenting anaerobe isolated from the caeca of a chicken. Int $J$ Syst Evol Microbiol 52, 921-925.

Whitehead, T. R., Cotta, M. A., Collins, M. D. \& Lawson, P. A. (2004). Hespellia stercorisuis gen. nov., sp. nov. and Hespellia porcina sp. nov., isolated from swine manure storage pits. Int J Syst Evol Microbiol 54, 241-245.

Wiegel, J., Tanner, R. \& Rainey, F. A. (2006). An introduction to the family Clostridiaceae. In The Prokaryotes. A Handbook on the Biology of Bacteria, 3rd edn, vol. 4, pp. 654-678. Edited by M. Dworkin, S. Falkow, E. Rosenberg, K. H. Schleifer \& E. Stackebrandt. New York: Springer-Verlag. 